\title{
Marburg Experiment on Surgical Research: A Five-Years' Experience on the Cooperation between Clinical and Theoretical Surgeons $* * *$
}

\author{
W. Lorenz, H. Hamelmann and H. Troidl ${ }^{* * *}$ \\ Division of Experimental Surgery and Pathological Biochemistry and Surgery Clinic of the University of Marburg (Lahn)
}

\author{
Marburger Experiment der chirurgischen Forschung. \\ Erfahrungen innerhalb 5 Jahren \\ über die Zusammenarbeit \\ von klinischen mit theoretischen Chirurgen
}

Zusammenfassung. Die Organisation der chirurgischen Forschung in Marburg ist ein Experiment, das seit fünf Jahren läuft und versucht, eine Kooperation zwischen klinischen und theoretischen Chirurgen zu installieren. Das Experiment wurde 1970 mit der Gründung einer Abteilung für Experimentelle Chirurgie und pathologische Biochemie an der chirurgischen Universitätsklinik begonnen. Strukturen und Funktionen in dem Experiment waren 6 ,kleine Arbeitsgruppen", spezielle Dienstleistungen für diese Gruppen und die gesamte Klinik und ein Ausbildungsprogramm für theoretische Chirurgen. Die Beurteilung von Erfolgen und Fehlleistungen bei dem Experiment erfolgte nach Kriterien, die drei Grundfunktionen chirurgischer Forschung prüfen sollten: (1) Ausbildung von klinischen und theoretischen Chirurgen in Methoden und Techniken chirurgischer Forschung, (2) Durchführung kontrollierter, klinischer Studien und (3) Grundlagenforschung in der Chirurgie. Die Frühergebnisse des Marburger Experiments erscheinen hoffnungsvoll.

Schliusselwörter: Chirurgische Forschung - Theoretischer Chirurg - Klinischer Kontrollversuch - Magenchirurgie.

\footnotetext{
* Presented at the meeting on "Gastric and duodenal ulcer disease : Basic principles and clinics of treatment by drugs and operations", Marburg, November 22, 1975

** Supported by the Deutsche Forschungsgemeinschaft (Ha 461/3) *** In cooperation with the following colleagues in our working teams: H. Barth, A. Doenicke, M. Fischer, J. Kusche, E. Lange, D. Maroske, H.-J. Reimann, H. Richter, H. Rohde, H. Schult, W. Seidel, C.D. Stahlknecht, R. Tauber, M. Thermann
}

Summary. The organisation of surgical research in Marburg is an experiment which has run for five-years and war carried out in attempt to establish a cooperation between clinical and theoretical surgeons (scientists in basic research). The experiment was started 1970 by creating a Division of Experimental Surgery and Pathological Biochemistry at the Surgery Clinic of the University. Structures and functions in this experiment were 6 small working teams, special services for the teams and for the whole Department of Surgery as well as a training programme in surgical research for theoretical surgeons. Success and failure in the experiment were evaluated by criteria testing three principal functions of surgical research: Training of clinical and theoretical surgeons in methods and techniques of surgical research, performance of controlled clinical trials and basic research in surgery. The early results of the Marburg experiment seem to be promising.

Key words: Surgical research - Theoretical surgeon - Controlled clinical trial - Gastric surgery.

In the history and philosophy of science (Reichenbach, 1951) surgical dexterity has been highly appreciated, but surgical research is rated to be of much lower value not only by investigators in classical physical sciences, but also by the surgeons themselves. F.D. Moore (1973) explains this order of precedence: "surgical research has all too often shown a lack of mastery of any clear scientific discipline rather than mastering techniques, and only occasionally contributing new methods that are useful to the rest of biological science".

However an empiricist or critical realist (Popper, 1972) readily finds surgical research where it is least 
expected-in the operating theatre and in clinical practice. If a surgeon in a series of truncal vagotomies without drainage frequently observes gastric ulcers, and if he regularly and reliably prevents their formation by adding either a pyloroplasty or a gastroenterostomy, he is as scientific as Galileo, finding that a stone thrown into air falls. There are no first- and second class observations, no first- and second class hypotheses, and, when new results contradict old theories, no first- and second class refutations.

The inaccurate self-understanding of surgical research caused critical developments which can easily be derived from the citation of Moore (1973). In the United States and in Scandinavia clinical surgeons tried to become biochemists and physiologists, and to a certain extent achieved this by advanced specialisation and restricting their routine work in academic surgery. These clinicians, however, have constantly to fight for full recognition both in the laboratory by the full-time investigators in basic sciences, and in the operating theatre by the surgical colleagues whose time is largely devoted to clinical work. We doubt whether this is the right way to do basic research in surgery or to achieve success in surgical science. In German-speaking countries general surgical training and clinical practice are regarded as more useful in patient care than extreme specialisation (Allgöwer, 1972), so that the individual surgeon cannot pursue the American and Scandinavian approach to surgical research for lack of time. However it is no answer to employ biochemists, physiologists and pathologists in hospital as a substitute for the surgeon himself learning basic sciences. When this happens clinicians and basic scientists work side to side often without mutual intellectual stimulation of immediate benefit to surgical research.

This incorrect appreciation has led to the neglect of whole fields of surgical research, especially methods for critical evaluation of surgical techniques. We consider that one of the chief merits of the British school of surgery is their emphasis for more than two decades on the importance of controlled trials in judging the success of surgical therapy (Goligher et al., 1956; Forrest, 1958). No clinical problem has been too unimportant to Goligher not to have tested it in a randomised trial, whether the advantages of a certain type of syringe (Goligher, personal communication) or those of a certain suturing technique (Goligher et al., 1975). This is intrinsic surgical research, and it is difficult to understand why many surgeons are still measuring enzyme activities and cardiac outputs instead of performing controlled trials of even the simplest everyday clinical problem.

For these reasons we in Marburg have developed a concept of surgical research adapted to the situation in Germany. Both clinical surgeons and workers in basic sciences have been integrated into special organisational structures. We report here our experience in the last five-years of this experiment presented in terms of an original communication.

\section{Materials and Methods}

1. Establishment of the Division of Experimental Surgery and Pathological Biochemistry at the Surgery Clinic

After preliminary discussions among themselves the authors of this study met several committees of the University and Governmental boards between summer 1969 and spring 1970. A plan for establishing a Division of Experimental Surgery within the Surgical Clinic was completed and filed on April 13, 1970 (Lorenz and Hamelmann, 1970), and may be considered conceptually as a prospective clinical study. The name and organisational structure of the Division, its status in the Department of Surgery, both integrated into, and autonomous within the clinic, were established in the format still existing today. The Divisional budget has mostly been met by province of Hessen and Deutsche Forschungsgemeinschaft. Compared with other scientific institutions in Germany our financial problems are "physiological", providing for staff (5 scientific workers including the Professor of the Division, 6 technicians, 1 secretary, 2 animal attendants, 2 cleaners, and 1 laboratory worker), for the biochemical, pharmacological, histological and surgical equipment and day to day expenses. About 600 square metres space was regarded as essential to provide for research laboratories, routine laboratories, and animal houses.

On December 27, 1970, the staff of the Division took up its work in Marburg, but it was not until April 1, 1971 that the first temporary rooms in a barrack, about 100 square meters, could be occupied. As so often, the temporary status lasted more than $4 \frac{1}{2}$ years. On September 1, 1975, the Division moved into its final quarters, within the Surgical Clinic, in the basement of the building containing the male ward.

\section{Structure and Function in Surgical Research in the Marburg Experiment}

2.1. The Small Working Team was regarded at the most important structure in the Marburg experiment for surgical research (Table 1) with the integration of clinical and theoretical research into a practicable, relatively long-lasting arrangement. The small working team was autonomous within the overall-concept of the Department of Surgery for surgical research. The size of the team allows this autonomy, but prevents total independency within the Clinic or the Division. Members of the team are chosen for their willingness to cooperate rather than competitive thinking. By lincting the group to a certain section of the overall programme of surgical research the possibility of causing conflicts between groups is minimized and the clinical and theoretical surgeons (see below) have maximum opportunities for fulfilling themselves.

The overall programme of "abdominal surgery, gastro-intestinal hormones and mediators with special reference to histamine" was divided between 6 teams: (1) Histamine and gastroduodenal ulcer; (2) histamine and abdominal shock with special reference to the liver; (3) histamine, proteolytic enzymes and acute pancreatitis; (4) diamine oxidase and intestinal ischemia; (5) mast cells, gastrointestinal hormones and stress ulcers; (6) histamine methyltransferase in the gastrointestinal tract and in chronic hydronephrosis. Each group was asked to investigate methodological aspects in 
Table 1. Organisation of the small working teams in the Marburg experiment on surgical research

\begin{tabular}{|c|c|}
\hline Principle: & $\begin{array}{l}\text { Integration of clinical and theoretical research } \\
\text { into a practical, relatively long-lasting arrangement }\end{array}$ \\
\hline Composition: & $\begin{array}{l}1 \text { theoretical surgeon, } 1 \text { or } 2 \text { clinical surgeons, } \\
1 \text { technician, } 1 \text { or } 2 \text { medical students }\end{array}$ \\
\hline Functions: & $\begin{array}{l}\text { Research on a distinct part of the scientific } \\
\text { programme of the Department consisting of: } \\
\text { A weekly discussion meeting } \\
\text { Planning and performing experiments } \\
\text { A follow-up research clinic } \\
\text { Documentation of case histories } \\
\text { in the research field } \\
\text { Specialized service for surgical care }\end{array}$ \\
\hline $\begin{array}{l}\text { Rooms and } \\
\text { Equipment: }\end{array}$ & $\begin{array}{l}1 \text { seminar room, } 1 \text { laboratory with the } \\
\text { necessary equipment, access to all the } \\
\text { apparatus of the Department }\end{array}$ \\
\hline
\end{tabular}

their field of surgery including quality control, standardisation of techniques, definition of measurements in clinical studies and the performance of controlled trials. As far as operative specialisation was concerned, the first and fifth group favoured gastric surgery, the second liver surgery, the third surgery of biliary tract and pancreas, the fourth surgery of small intestine, colon and rectum and the sixth urological surgery. All 5 theoretical surgeon and 10 of the 28 clinical surgeons in the surgical clinic took part in the various teams.

The composition, functions and research facilities of the small working teams are shown in Table 1. The worker in basic research ("theoretical surgeon"- - see below) needs an adequate training in one of the disciplines of basic science. At the beginning of our experiment this was the case in only one member of the staff The clinical surgeon in our small working teams should have had 3 to 4 years training in clinical surgery to demonstrate his operative ability. Surgical research should not be used to compensate awkwardness in the operating-theatre. At the beginning of our experiment this was easy to establish since there was a wide choice of clinical surgeons available. The clinical surgeon should do his research in the team for $2-3$ years while continuing full time his work in the clinic (pre-habilitation grade). Then after completion of his specialist training he should for one year do research exclusively to perform the habilitation thesis (habilitation grade). The habilitation in Germany today is an examination for testing a subject being able to teach students and to do research independent from a professor. It is - as a rule--prerequisite for getting later on a professor, ship in medicine. For habilitation - as a rule - a thesis of about 100-200 pages is necessary, a series of scientific papers and an interview by the professors of the faculty of medicine (disputation). Finally the candidate has to give his first lecture for students as an official ceremony for being introduced as a teacher at university.

After habilitation the clinical surgeon should remain in the team, but after some time more and more of the experimental work should be handed over to a second, younger clinical surgeon for his pre-habilitation time.

The functions of the small working teams are shown in Table 1 as well: (1) The weekly round-table discussion (always at exactly same time during the week) included talks about the latest experiments, planning of new experiments, information on recently published or recently discovered literature on the projects of the team. It also included the evaluation of measurements and results, preparation of publication and discussion of personal problems within the team. (2) The follow-up clinic, at first every two weeks, included not only the clinical and the theoretical surgeons but also a physician and sometimes also a psychologist (duodenal ulcer as a psychosomatic disease). 10 to 16 of the patients of interest for the individual team were checked by questionnaires and various reports from other specialized units, such as clinical chemistry, X-ray, and histopathology. For example the gastric surgery follow-up clinic was held every Thursday from $10.00-14.00 \mathrm{~h}$ since on Thursday only emergency surgery is carried out in our clinic. (3) Special clinical investigation were also part of scope of the team. For example, in gastric surgery these included endoscopy and gastric secretory tests. The follow-up clinic and the special routine services mainly supported the training and development of the theoretical surgeon in the clinical sciences. This objective was pursued by re-examination of medical histories relating to the special topic of the team from photocopies of the original case-notes. (4) The experiments were also carried out with each member having a specific role. The theoretical surgeon obtained from the literature the necessary information in advance. He organized and supervised the planning, and assisted in the operations performed in patients or animals. The clinical surgeon carried out and supervised the surgical parts of the experiment and guaranteed the validity of the clinical part of the study by his clinical experience and his knowledge of the clinical literature. The technicians and medial students performed the laboratory tests which, due to the biochemical specialisation of the Division, were a considerable part of the whole experiment.

The research facilities for each team are listed in Table 1.

2.2. Services for the Small Working Teams. Due to the chronic lack of time of the clinical surgeons and the overwhelming flood of information (literature, apparatus, techniques, drugs etc.) in the surgical sub specialties it was found useful to centralise certain functions to one theoretical surgeon. The theoretical surgeon could so obtain useful knowledge in special disciplines, while the clinical surgeons would not waste their spare time for research on unnecessary organisational and administrative problems. Furthermore, this procedure seemed appropriate since in any case the theoretical surgeons had to carry out this work for themselves.

The services included obtaining reprints and library material, ordering and maintenance of apparatus, purchase of glass ware and chemicals, supervision and organisation of the animal-houses, and finally advise in writing publications. Each of these functions was taken over by one theoretical surgeon, not only for the Division of Experimental Surgery, but also for every clinical surgeon in the various teams. For this purpose he had additional helpers.

Obtaining reprints and photocopies of scientific papers held a special position among the services. The theoretical surgeon in charge obtained lists of journals from central libraries in Germany as well as from many institntes near our Department. He established contacts with the University Library, German Institute of Medical Documentation and Information (DIMDI), the computerised central documentation offices of various industrial companies and with the Institute of Scientific Information (ISI), Philadelphia. The request for reprints for the individual scientists was done on standardized forms through a special office controlled by this theoretical surgeon. The documentation of the reprints received was done by each individual scientist himself according to a mutually acceptable system adopted by all the clinical and theoretical surgeons. The many copies required were produced centrally by a laboratory worker.

2.3. Services for the Department of Surgery. Since in our opinion the establishment of a Division of Experimental Surgery can only be justified if the theoretical surgeons also have permanent functions, several schemes for surgical research were set up for the whole Department of Surgery. These included (1) a weekly twohour round for training in surgical research, (2) advising members 
Table 2. Training of scientists working exclusively in surgical research with the aim of obtaining the equivalent of a diploma of "specialist in theoretical surgery"

\begin{tabular}{|c|c|}
\hline Training of theore & etical surgeons \\
\hline General training & \\
\hline Surgery & (assisting clinical surgeons during operations) \\
\hline $\begin{array}{l}\text { Clinical } \\
\text { chemistry }\end{array}$ & $\begin{array}{l}\text { (quality control, tests of reliability } \\
\text { of methods, statistics) }\end{array}$ \\
\hline $\begin{array}{l}\text { Clinical } \\
\text { pharmacology }\end{array}$ & $\begin{array}{l}\text { (pharmacokinetics, pharmacodynamics, } \\
\text { research on side-effects of drugs, bio-assays) }\end{array}$ \\
\hline Special training & \\
\hline $\begin{array}{l}\text { Education in bi } \\
\text { or in any other } \\
\text { or education in }\end{array}$ & $\begin{array}{l}\text { Wochemistry-physiology-pharmacology, } \\
\text { kind of theoretical discipline } \\
\text { clinical surgery }\end{array}$ \\
\hline
\end{tabular}

of the Department who were not part of small working teams in arranging clinical or experimental studies, and in writing communications and papers, (3) advising these members in statistical problems and the use of computers, (4) advise in ordering and maintaining apparatus and (5) central care of the animal house and advise in the choice of experimental animals for specific scientific problems.

The two-hour round like the concept of the small working team was regarded as an essential part of surgical research. For 4 years it has taken place on a Thursday afternoon, at which time there are fewest emergency operations. The first of the two hours of discussion was devoted to the advancement of clinical training, and the second hour was spent on training in basic sciences related to surgery. A defined programme for the colloquia was established. Series of presentations were arranged on certain clinical subjects, such as gastrointestinal surgery, pancreatic surgery, as well as some methodological subjects (statistics, controlled trials, quality control). There was an additional series of progress reports of the teams, and of members of the Department of Surgery not participating in teams. Finally this round was also used for presentations by foreign scientists.

2.4. Training of Theoretical Surgeons. Despite there having been in Germany for several decades a discipline 'Experimental Surgery" there exists still no education and training scheme for workers in this field. Since we were convinced that such a training programme was essential for professional success of scientists in surgical research we developed the concept of the "theoretical surgeon". This term was used first in Marburg 1974 by Rudolf Zenker on the occasion of a habilitation ceremony, and we think that this title could help to create a new professional qualification (Table 2).

General training for about 3 years should be fulfilled by all theoretical surgeons together with sub specialty training in one of the disciplines listed in Table 2. In Britain some physicians may be characterized as theoretical surgeons who guarantee a very high standard in this discipline, for example J.H. Baron and P. Ganguli. Thus specialisation in Internal Medicine may be considered as another possible training for a theoretical surgeon.

The surgical training (Table 2) should not be dominated by operative techniques which, simply from lack of time, could qualitatively never permit to achieve respectable levels without limiting the training in surgical research. Preferably the theoretical surgeon should assist in a certain number of operations chosen from the operation catalogue for specialists in clinical surgery (Table 3) and
Table 3. Catalogue of operations in which theoretical surgeons are obliged to assist clinical surgeons for their general training in surgical research.

The numbers behind the single operations correspond to the number of operations in which assistance is required

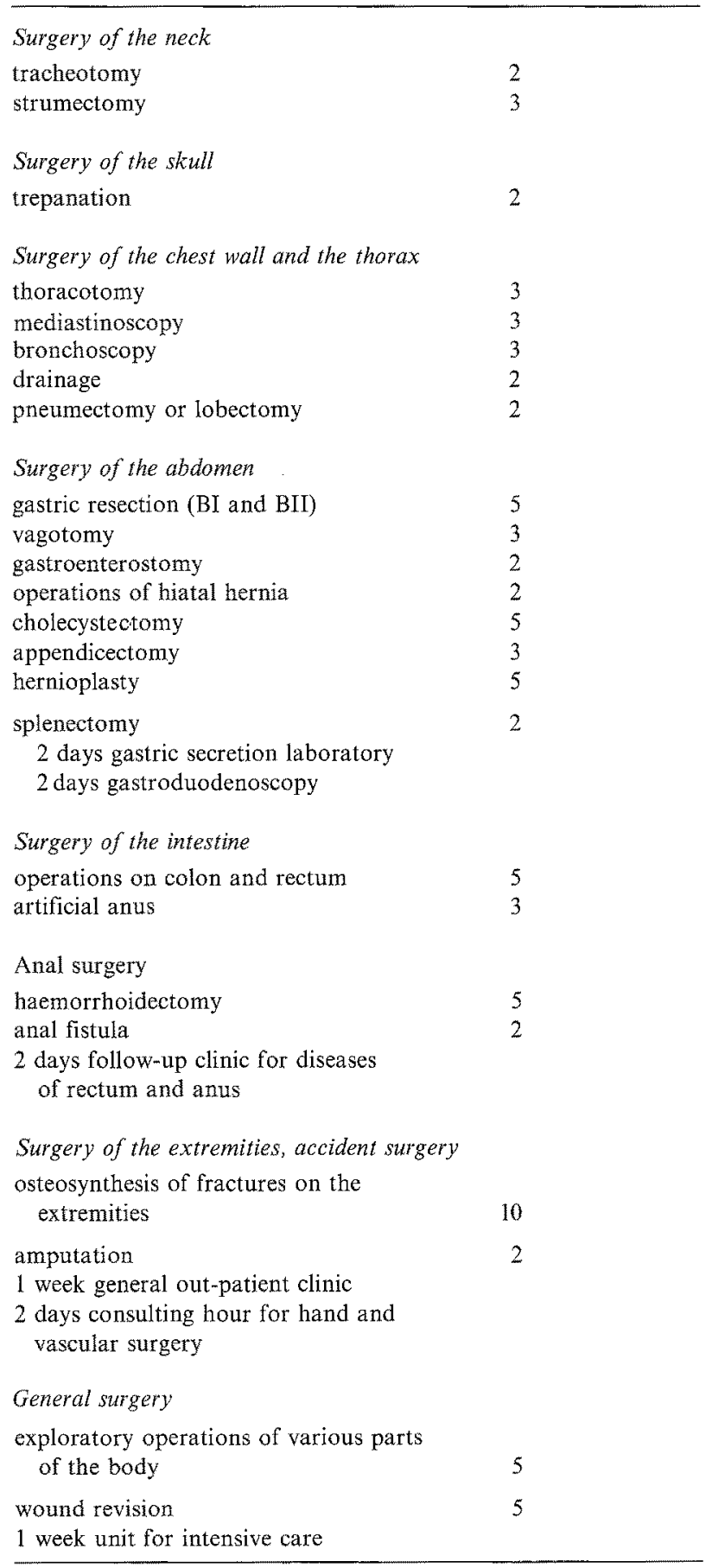

should learn to understand the various steps in the course of an operation.

We consider that in the present situation in Germany the completion of the training of a theoretical surgeon should consist only of a habilitation. This academic degree should include a scientific qualification, the fulfilment of the training programme in Ta- 
Table 4. Three principal functions of surgical research

Training of clinical and theoretical surgeons

in methods and techniques of surgical research

Performance of controlled trials

Basic research in surgery

ble 2 and the principal authorship of at least one major clinical communication.

3. Evaluation of Success and Failure in Surgical Research in the Marburg Experiment

There were many problems in establishing criteria for evaluating the success or failure of the Marburg Experiment with respect to improvement of surgical research. The biochemical measurements can be regarded as relatively reliable, that of clinical measurements of symptoms are much less accurate, so that the evaluation of success or failure of a model for surgical research has been extremely difficult. The main problems were of defining success or failure in all these complex fields, both scientific and ethical, but there were also prejudices on the part of the participants in the teams (pro) and of the outsiders (contra) in our Department.

We have therefore set up two groups of criteria of success in this early phase of our experiment:

(1) Practicability concerning expenses in time and money, number of publications in highly qualified journals and number of academic degrees as well as improvement in hospital care in our Department. Of course all these criteria may be vigorously criticised because they depend on so many conditions other than a given organisational structure. "Research about research" needs to discuss more viable criteria for measuring success or failure in research. Only a few steps have been taken in this direction (Aaronson, 1975) so that it seems too early to start a controlled trial on the success of surgical research in different organisational systems.

(2) The second group of criteria concerned three of our requirements for surgical research (Table 4). We were not using these criteria to test whether the Marburg experiment was better than other organisational structures for surgical research, but only whether it was suitable in principle for fulfiling these functions of surgical research.

\section{Results}

\section{Training of Clinical and Theoretical Surgeons in Methods and Techniques of Surgical Research}

Two-hour round. In the last 4 years the topics presented in Tables 5 and 6 have been discussed in the two-hour round. Since this round was first established on a voluntary basis only $10-15$ persons took part during the first year and most of these were scientists of the several small working teams. Recently published reviews and books formed the scientific basis for the round, for example, the book by Snedecor and Cochran (1967) on statistics, on quality control the article by Büttner et al. (1970) and the book by Steffen (1968) on immunology. The success of the
Table 5. Topics presented in the clinical part of the round for training in surgical research (1971-1975)

\begin{tabular}{|c|c|}
\hline Stomach & $\begin{array}{l}\text { Pathophysiology of the stomach } \\
\text { Clinical aspects of diseases of the } \\
\text { stomach and duodenum } \\
\text { Gastric surgery } \\
\text { Techniques in the follow-up clinic } \\
\text { Tests of gastric secretory functions } \\
\text { Psychosomatic aspects of ulcer disease }\end{array}$ \\
\hline $\begin{array}{l}\text { Liver, gall- } \\
\text { bladder and } \\
\text { pancreas }\end{array}$ & $\begin{array}{l}\text { Pathogenesis of pancreatitis } \\
\text { Therapy of pancreatitis } \\
\text { Therapy of acute cholecystitis } \\
\text { Liver transplantation }\end{array}$ \\
\hline Gut & $\begin{array}{l}\text { Pathophysiology of intestinal ischemia } \\
\text { Surgery of colon and rectum }\end{array}$ \\
\hline Shock & $\begin{array}{l}\text { Plasma substitutes and their side-effects } \\
\text { Burns }\end{array}$ \\
\hline
\end{tabular}

Table 6. Topics presented in the theoretical part of the round for training in surgical research (1971-1975)

\begin{tabular}{|c|c|}
\hline \multirow[t]{3}{*}{ Statistics } & $\begin{array}{l}\text { Sampling of attributes, randomization, } \\
\text { parameters, histograms, comparison of relative } \\
\text { frequencies }\left(\chi^{2} \text {-test) }\right.\end{array}$ \\
\hline & $\begin{array}{l}\text { Normal distribution (Student's t-test, t-test for } \\
\text { paired data) }\end{array}$ \\
\hline & $\begin{array}{l}\text { Frequency distribution significantly different } \\
\text { from normal or an unknown type of frequency } \\
\text { distribution (Mann-Whitney test, Wilcoxon test) }\end{array}$ \\
\hline \multirow[t]{2}{*}{ Surgery } & Controlled trials from every fields of surgery \\
\hline & Basic principles of documentation \\
\hline \multirow{4}{*}{$\begin{array}{l}\text { Clinical } \\
\text { chemistry } \\
\text { and } \\
\text { biochemistry }\end{array}$} & Quality control \\
\hline & Proteases \\
\hline & Coagulation, fibrinolysis \\
\hline & Complement system \\
\hline \multirow[t]{2}{*}{ Pharmacology } & $\begin{array}{l}\text { Techniques for measuring blood pressure and } \\
\text { blood flow }\end{array}$ \\
\hline & Methods for determining oxygen tension in tissues \\
\hline \multirow{2}{*}{$\begin{array}{l}\text { Pathology- } \\
\text { Immunology }\end{array}$} & Mast cells \\
\hline & $\begin{array}{l}\text { Basic knowledge in allergy and immunology } \\
\text { of transplantation }\end{array}$ \\
\hline
\end{tabular}

round as an institution for training in surgical research was an increasing number of participants of up to $20-30$ persons after about one year. This increase in participation was looked upon as a creation of interest. About 3 months ago a questionnaire was submitted to all participants, and the results favoured the continuation of the round. Successful features of the round included:- Recognition of the scientific service by everyone, greater clarity of research within the Department, usefulness of this training for the individuals research, improvement of medical care by critical testing of the various therapeutic regimes used in the Department. The time spent for the round 
Table 7. Prospective and controlled clinical trials 1971-1975

\begin{tabular}{llll}
\hline Topic & $\begin{array}{l}\text { Number of Problem } \\
\text { subjects }\end{array}$ & Result \\
\hline $\begin{array}{l}\text { Gastric secretory } \\
\text { tests }\end{array}$ & 20 & $\begin{array}{l}\text { Suction by hand versus suction by pump } \\
\text { (randomized) }\end{array}$ & No difference in accuracy \\
$\begin{array}{l}\text { Histamine release } \\
\text { by plasma substitutes }\end{array}$ & 40 & $\begin{array}{l}\text { Haemaccel }{ }^{\oplus} \text { versus Macrodex }{ }^{\oplus} \text {, Gelifundol }{ }^{\circledR} \\
\text { and Plasmasteril }{ }^{\circledR} \text { (randomized) }\end{array}$ & $\begin{array}{l}\text { All these drugs release histamine in man, } \\
\text { but incidence and severity of reaction may } \\
\text { be different }\end{array}$ \\
$\begin{array}{l}\text { Operations for } \\
\text { duodenal ulcer }\end{array}$ & 138 & $\begin{array}{l}\text { Individual choice of operation versus SV } \\
\text { with drainage (consecutive) }\end{array}$ & $\begin{array}{l}\text { No difference in hospital mortality rate, } \\
\text { more recurrent ulcers in case of SV } \\
\text { with drainage }\end{array}$ \\
$\begin{array}{l}\text { Surgery of colon } \\
\text { and rectum }\end{array}$ & - & $\begin{array}{l}\text { Pretreatment with antibiotics or not } \\
\text { (randomized) }\end{array}$ & in performance \\
\hline
\end{tabular}

seemed acceptable, the regularity of its performance was welcomed, and the scientific standard of questions and answers was felt to be markedly raised (less of "my experience is that..." and "I believe that..."; more of "controlled trial showed that...").

Almost all the failures of the round were due to discrepancies between the clinical and theoretical medicine, which was hardly surprising considering the deep gap which is unfortunately separating these two fields of medicine. Good will and the best personal understanding could only alleviate but not abolish this contrast. The problems were either presentation of material too complicated for the clinical surgeon or vice versa for the theoretical surgeon, a lack of motivation ("for which clinical problem do I need these special enzyme kinetics?") or absence of interest in the whole subject. Over-long presentation of a single subject and lack of continuity from repeated absence of members of the audience also had a negative effect.

It can be seen from the above successes that we had to go through a learning process for our problems. This learning process has reached a very satisfactory stage, but has been considerably impeded by the occasional lack of reliable concepts, by "regressions back to earlier phases of our scientific development" and last, but not least, by the extraordinary professional situation of a clinical surgeon in Germany (operations to be performed nearly every day of the week, clinical work for about $70 \mathrm{~h}$ a week including two nights on duty, and the expectation of being summonsed at any time and by everybody).

Small Working Team. The problems which had arisen in the two-hour round could more easily be solved in the meetings of the teams because of the smaller number of participants. More active questioning in the teams enforced more exact explanations of the ideas, and more motivation could be provided for learning unusual methods and subjects. The presence of technicians and medical students also had positive effects, providing more detailed explanations of experiments and their scientific background. Training within the teams turned out to be more problemrelated, and therefore could not replace the basic training presented in the round.

\section{Performance of Prospective and Controlled Clinical Trials}

Four prospective clinical trials have been started so far (Table 7) and have reached different stages. The problem of histamine release and anaphylactoid reactions caused by four plasma substitutes (Haemaccel ${ }^{\circledR}$, Macrodex ${ }^{\circledR}$, Gelifundol ${ }^{\circledR}$ and Plasmasteril ${ }^{\circledR}$ ) was tested in a randomised clinical trial (Lorenz et al., 1976). The reliability of mechanical suction of gastric juice versus suction by hand for testing maximum gastric secretory response was tested in a randomised study of 20 subjects (Troidl et al., 1973). Already in the middle of 1970 a long-term study has been started in the field of duodenal ulcer surgery to compare an individual choice of operation with selective gastric vagotomy with drainage alone (Seidel et al., 1973). The two series of operations were carried out consecutively and were immediately followed by a third series, selective proximal vagotomy without drainage, as a basis for a randomised controlled trial in an attempt to prevent bad results of operations for duodenal ulcer (Visick IV). Finally, a prospective randomised trial of the value of antibiotic therapy in the surgery of colon and rectum was been initiated by H. Richter, J. Kusche and C.D. Stahlknecht.

Positive aspects and problems of our controlled trials are shown in Table 8 , and some of these have been discussed in detail (Lorenz and Rohde, 1973). We were all astonished how much a 98-100 per cent follow-up increased our clinical knowledge since most patients who were very satisfied or totally disappoined 
Table 8. Positive aspects and problems of controlled clinical trials in surgery $1971-1975$

\begin{tabular}{ll}
\hline Positive & Experience increased by $98-100 \%$ follow-up \\
aspects: & $\begin{array}{l}\text { Surgical care improved } \\
\text { Documentation of case histories improved }\end{array}$ \\
Problems: & $\begin{array}{l}\text { Expenditure in time too great } \\
\text { Tedious work not enough appreciated } \\
\text { Continuity not guaranteed in case of long-term studies }\end{array}$ \\
\hline
\end{tabular}

Table 9. Histamine release by plasma substitutes: An example for consecutive publications of surgical research both in basic science journals and in clinical journals

See references under Lorenz et al. (1974a-d, 1976a)

\begin{tabular}{|c|c|}
\hline Title of publication & Journal \\
\hline $\begin{array}{l}\text { Fluorometric histamine determination in } \\
\text { canine plasma at normal conditions } \\
\text { following application of exogenous } \\
\text { histamine and during histamine release } \\
\text { by Haemaccel }\end{array}$ & $\begin{array}{l}\text { Hoppe-Seyler's } \\
\text { Z. Physiol. Chem. } \\
\text { 355, 1097-1111 } \\
(1974 \text { a) }\end{array}$ \\
\hline $\begin{array}{l}\text { Problems in the assay of histamine } \\
\text { release by gelatin: o-phthaldialdehyde- } \\
\text { induced fluorescence, inhibition of } \\
\text { histamine methyltransferase and } \\
\mathrm{H}_{1} \text {-receptor antagonism by Haemaccel }\end{array}$ & $\begin{array}{l}\text { Agents and } \\
\text { Actions } \\
\text { 4, 324-335 (1974b) }\end{array}$ \\
\hline $\begin{array}{l}\text { Evaluation of histamine elimination } \\
\text { curves in plasma and whole blood of several } \\
\text { circulatory regions: A method for studying } \\
\text { kinetics of histamine release in the } \\
\text { whole animal }\end{array}$ & $\begin{array}{l}\text { Agents and } \\
\text { Actions } \\
4,336-356(1974 \mathrm{c})\end{array}$ \\
\hline $\begin{array}{l}\text { Elevated plasma histamine concentrations } \\
\text { in surgery: causes and clinical significance }\end{array}$ & $\begin{array}{l}\text { Klin. Wschr. 52, } \\
\text { 419-425 (1974d) }\end{array}$ \\
\hline $\begin{array}{l}\text { Histamine release in human subjects by } \\
\text { modified gelatin (Haemaccel }{ }^{\circledR} \text { ) and dextran: } \\
\text { Explanation for anaphylactoid reactions } \\
\text { observed under clinical conditions? }\end{array}$ & $\begin{array}{l}\text { Brit. J. } \\
\text { Anaesthesia 48, } \\
151-165 \text { (1976a) }\end{array}$ \\
\hline
\end{tabular}

with the results of a particular operation tried to evade the follow-up.

\section{Basic Research in Surgery}

Clinical and theoretical surgeons find this aim of surgical research the last controversial. However it is often forgotten that only reliable methodology justifies clinical research from the scientific point of view and--since the findings are to be applied to human subjects-especially from the ethical point of view.

We therefore developed a technique to solve this problem, which can be best demonstrated by one of our publications (Table 9). First, reliable methods in basic sciences and clinical research were developed to solve a particular problem. Then animal experiments and clinical investigations were performed. The
Table 10. Positive aspects of basic research in surgery in the Marburg experiment on surgical research

None of the small working teams have had to be dissolved so far Both "cutters" and "thinkers" progressed in personal development ("Habilitation")

Individual contribution to work could be estimated by scientists outside the team

Clinical and theoretical parts of work were integrated

Interest in research was established, not merely interest in career Conflict between working teams was kept on a low level

results were published quickly in appropriate journals, i.e. in both basic science journals and clinical journals. In this way we tried to meet the criticisms of basic sciences as well as those of clinical sciences, but unfortunately in some cases only with doubtful success. Furthermore, we undertook this series of publications to be direct proof of the integration of basic and clinical research in the field of surgery. The success of this scheme paralleled that of the team. About 5 years were needed for this series of publications, and in 6 cases ( 5 clinical surgeons, 1 theoretical surgeon) this work has already resulted in an habilitation. The positive aspects of such a procedure in surgical basic research are listed in Table 10. We consider it as a success that none of the small working teams have had to be dissolved so far. On the contrary, there was increasing integration between the clinical and basic-science parts of the research in the teams. It became more and more impossible for publications to be written solely by either the clinical or the theoretical surgeon when, for example, problems of clinical diagnosis coincided with problems of clinicalchemical measurements (Troidl et al., 1976). An essential step from cooperation to integration has thus been made, there is increasing evidence that this process is selfperpetuating in each small working team.

Furthermore, conflict between the teams was kept at a low level, since each of the teams had its own scientific topic which has not been contested by any of the other groups. Thus a feeling of security developed with a simultaneous decline in inter-team conflicts. It was even possible for one team to take over into their own programme certain methods which had been developed by another team simply by co-opting the other group. At first the rule that certain methods or topics were alloted to one team only was looked upon as a compulsory regulation, but the advantages of this procedure soon became evident. For whoever had the privilege of a method also had the obligation of service, and the results of these cooperative studies were always published jointly. Both the stimulus and the pressure to cooperate have so far prevented any withdrawal by any of the teams. 
Table 11. Problems of basic research in surgery in the Marburg experiment on surgical research

First: The clinical surgeon

Too much expenditure of time for personal development

Continuity not guaranteed after "Habilitation")

Steps from basic research to clinical research need too much time

"Too many ideas and too little working capacity"

Too much confusion concerning time for surgical care and research

Second: The theoretical surgeon

Narcissism of theoretical medicine

Sample taking difficult under clinical conditions

"Man differs from guinea-pig by his personal history"

Difficulty in obtaining or maintaining his competence in a theoretical discipline

Work not appreciated by theoretical medicine

The problems of our procedure in surgical research were at least as numerous as the successes (Table 11).

(1) The problems of the clinical surgeon: Because of the clinical competition for promotion he sometimes felt that the time for the habilitation was too long, especially when he saw how colleagues from other surgical departments were appointed assistant professors having spent considerably less time on research.

However, a few months after habilitation he might be offered the post of medical director of a hospital, upsetting the planning and continuity of research by the team.

The development of methods in basic sciences might take several years, and a clinical surgeon understandably might find it hard to wait for this step from basic research to clinical research.

In practice, however, the clinical surgeon came across unsolved medical problems every day. It was difficult for him to persist with a project once it was under way, and to restrict himself to only a few subjects.

Last, but not least, he faced difficulties with his research work and intellectual concentration because of the hospital staff would disturb him at any time, even when off-duty, often for unimportant reasons (according to the clinical surgeon's view).

(2) Problems of the theoretical surgeon (Table 11): He constantly had to fight a tendency to be satisfied with his basic-research part in the team. Too often he himself became a victim of his own narcissism, a characteristic of theoretical medicine of today. Among the clinical surgeons of our teams familiar quotations circulated:- "only research on the black tail of a white mouse" or "again only rat surgery".
It was very difficult for the theoretical surgeon to become motivated by clinical practice.

There were problems in organising the collection of samples of blood or tissue in the clinic, but the making of appointments with volunteers and the sampling at endoscopy proved a way out of the dilemma (Lorenz et al., 1976a; Troidl et al., 1976).

It was clear that a controlled trial in human subjects could not be standardized like a test with inbred mice. When we discovered that in contrast to guineapigs human subjects were to be understood as historical beings we felt almost as if we had broken through intellectually into a new dimension. For example, while analysing the data about the histamine content of the gastric mucosa of control subjects and of patients with duodenal ulcer (Troidl et al., 1976) was exemplified this problem by the following question:Is a patient still a normal subject when his case history once showed a gastritis? If not, where can control subjects be found, considering that gastritis occurs so often?

Besides these intrinsic problems of surgical research the theoretical surgeon was confronted with the difficulty of following developments in the field of basic research since his working hours were finite. It was hard to put up with mediocrity at the price of interdisciplinary originality. The rejection and disregard of most basic-research scientists was a crushing blow, and their narromindedness became a main problem of the theoretical surgeon. These special problems of the clinical and theoretical surgeons within the team became apparent when manuscripts of papers and abstracts of communications were refused. These rejections regularly argued that "the publication was oriented too much to clinical practise or to basic research". These rejections or requests for "major revision" of publications led to disputes between the clinical and the theoretical surgeon of the team whether in future the project should be orientated more to clinical practise or more to basic research.

\section{Discussion}

Several clinical surgeons (Moore, 1973; Bücherl, 1974; Willenegger, 1974; Heberer et al., 1974) have discussed the nature of surgical research and criticised its quality. From the article of Bücherl (1974) the general comment can be derived. "We are able to feel some sort of uneasiness and would like to explain it". Our Marburg experiment is no more than a attempt to show whether - with a maximum of good will for cooperation in a team-clinical surgeons and basicresearch scientists would work together under certain circumstances, i.e. work in a situation where each 
partner had the same rights. Up to now we regard our experiment as a success, but long-term results are not available.

Our experiment can be criticised in theory from various points of view, and the problems mentioned in this report could be cited against us. The decision about success or failure, however, can only be made from the results of experiments and a refutation can come only as a result of other practical work. A main objection to the Marburg experiment has been its foundation on favourable personalities and not on favourable structures ("one simply gets on well with one another, and this could change"). This objection seems unjustified since in this respect only one of the two components (persons and structure) of a satisfactory cooperation was omitted as a risk factor. Since our problems were not particularly personal problems, they must be looked at more seriously as structural problems. The concrete description of our failures seemed to us the most important part of our experiment, since our failures could stimulate further experiments, and we ask others to take the initiative. In our opinion it is more important to describe the difficulties in cooperation which we had, than to mention our successes. We have described the equipment of the Division of Experimental Surgery, because we wanted to make it easier to assess this factor, which greatly influenced the results of our cooperation and which could in the long run be critical for surgical research in our experiment.

On the basis of our experiment we see several opportunities for development of surgical research:

(1) Small hospitals would be able to carry out certain controlled trials or take part in such trials if they received the necessary resources in clinical science. The same point has been made by the osteosynthesis study group (Willenegger, 1974). This improvent in critical scientific engagement would have a positive effect in improving clinical care. Furthermore it is particularly important for surgical research to obtain results outside University clinics, since for most people the medical care is effected under completely different conditions. Clinical research is needed in district hospitals.

(2) The introduction and maintenance of a service in clinical science for a University clinic as well as for the smaller hospitals in the district would require a theoretical surgeon, who would have a real permanent function similar to that of a clinical chemist or of a clinical pharmacologist. The creation of the profession of a theoretical surgeon would permanently improve surgical research.

(3) We are convinced that it is possible for the clinical surgeon to maintain the necessary unity in medicine: medical care, research and teaching without extreme specialisation. But the "omniscient" individual has to be replaced by the "team". In addition the formation of teams also facilitates training in surgical research. It seems no longer necessary for a young clinical scientist to disappear from the clinic for 6 or 12 months to work in an Experimental Surgery Unit and stopping research after habilitation or for him to go to America for some months just to do a little work in a field of basic science and then "write some papers" after having been introduced to the teams there as a laboratory aid. All these training facilities which so far have been available have been of questionable value for surgical research.

Finally we had to decide whether the Marburg experiment - in whole or in part - was also applicable to other clinical disciplines. Cooperation with an anaesthetic department has worked (A. Doenicke in Munich). In Marburg there exists also a team successfully cooperating with the urological clinic in research on hydronephrosis (Barth et al., 1975). We are therefore convinced that our experiment could also stimulate discussion about clinical research in other medical fields.

We are very gratefui to H.J. Baron, F.T. DeDombal, P. Ganguli and D. Johnston for exciting discussions on the problems of surgical research and a very useful criticism of this publication.

\section{References}

1. Aaronson, St.: The footnotes of science. Mosaic 6, 22 (1975)

2. Allgöwer, M.: Interdisziplinäre Zusammenarbeit in der Chirurgie. Ther. Unsch. 29, 645 (1972)

3. Barth, H., Naber, K., Barthel, K.E., Niemeyer, I, Lorenz, $\mathrm{W}$. : Induction of histamine methyltransferase during experimental hydronephrosis: A mechanism of adaptation for histamine homeostasis in rabbit kidney. Agents and Actions 5, 442 (1975)

4. Büttner, H., Hansert, E., Stamm, D.: Auswertung, Kontrolle und Beurteilung von Meßergebnissen, in: Handbuch der enzymatischen Analyse (Ed. H.U. Bergmeyer) Verlag Chemie, p. $281(1970)$

5. Bücherl, E.S. : Das Dilemma der chirurgischen Forschung. Chirurg 45, 485 (1974)

6. Forrest, A.P.M.: The treatment of duodenal ulcer by gastroenterostomy, gastroenterostomy and vagotomy and partial gastrectomy. Gastroenterologia 89, 307 (1958)

7. Goligher, J,G., Moir, P.J.: The Billroth-I and polya operations for duodenal ulcer. Lancet I, 225 (1956)

8. Goligher, J.G., Irvin, T.T., Johnston, D., DeDombal, F.T., Hill, G.L., Horrocks, J.C.: A controlled clinical trial of three methods of closure of laparotomy wounds. Brit. J. Surg. 62, 823 (1975)

9. Heberer, G., Brendel, W., Schildberg, F.W., Feifel, G.: Aufgabe und Organisation chirurgisch-klinischer Forschung. Chirurg 45, 490 (1974)

10. Lorenz, W., Hamelmann, H.: Vorstellungen von einer Abteilung für Experimentelle Chirurgie an der Chirurgischen Klinik der Universität Marburg. Letter to the Chancellor of the University of Marburg, April 13, 1970 
11. Lorenz, W., Doenicke, A., Thermann, M.: Spezielle Gesichtspunkte von Allergie und Anaphylaktoidie bei den in der Narkose verwendeten Pharmaka. Wissensch. Mitt. Freseniusstiftung 135 (1976)

12. Lorenz, W., Rohde, H.: Probleme bei der Durchführung einer prospektiven kontrollierten Studie über chirurgische Behandlungsmethoden. Klin. Wschr. 51, 475 (1973)

13. Lorenz, W., Barth, H., Thermann, M., Schmal, A., Dormann, P., Niemeyer, I.: Fluorometric histamine determination in canine plasma at normal conditions, following application of exogenous histamine and during histamine release by Haemaccel $^{\odot}$. Hoppe-Seyler's Z. physiol. Chem. 355, 1097 (1974a)

14. Lorenz, W., Barth, H., Karges, H.E., Schmal, A., Dormann, P., Niemeyer, I.: Problems in the assay of histamine release by gelatin: o-phthaldialdehyde-induced fluorescence, inhibition of histamine methyltransferase and $\mathrm{H}_{1}$-receptor antagonism by Haemaccel ${ }^{\circledR}$. Agents and Actions 4, 324 (1974b)

15. Lorenz, W., Thermann, M., Messmer, K., Schmal, A., Dormann, P., Kusche, J., Barth, H., Tauber, R., Hutzel, M., Mann, G., Uhlig, R. : Evaluation of histamine elimination curves in plasma and whole blood of several circulatory regions: a method for studying kinetics of histamine release in the whole animal. Agents and Actions 4, 336 (1974c)

16. Lorenz, W., Seidel, W., Doenicke, A., Tauber, R., Reimann, H.-J., Uhlig, R., Mann, G., Dormann, P., Schmal, A., Häfner, G., Hamelmann, H.: Elevated plasma histamine concentrations in surgery: Causes and clinical significance. Klin. Wschr, 52, 419 (1974d)

17. Lorenz, W., Doenicke, A., Messmer, K., Reimann, H.-J., Lahn, W., Beez, K., Schmal, A., Dormann, P., Thermann, M., Hamelmann, H.: Histamine release in human subjects by modified gelatin $\left(\mathrm{Hacmacce}^{\circledR}\right)$ and dextran: explanation for anaphylactoid reactions observed under clinical conditions? Brit. J. Anaesth. 48, 151 (1976a)

18. Moore, F.D.: What is surgical research? Europ. Surg. Res. 5, $245(1973)$
19. Popper, K.R.: Objective knowledge. The Clarendon Press Oxford, 1972

20. Reichenbach, H.: The rise of scientific philosophy; University of California Press, Berkeley and Los Angeles 1951

21. Seidel, W., Troidl, H., Lorenz, W., Rohde, H., Richter, H., Drews, H., Hamelmann, H.: Eine prospektive, kontrollierte Studie zur selektiven Vagotomic beim chronischen Duodenalulkus: Frühergebnisse mit einer standardisierten Operationsauswahl und Operationstechnik. Klin. Wschr. 51, 477 (1973)

22. Snedecor, G.W., Cochran, W.G.: Statistical methods, 6 th ed. The Iowa State University Press, Ames, Iowa (1967)

23. Steffen, C.: Allgemeine experimentelle Immunologie und Immunpathologie und ihre klinische Anwendung. Thieme-Verlag, Stuttgart, 1968

24. Troidl, H., Lorenz, W., Hegewald, C., Rohde, H., Acker, G., Seidel, W.: Präzision von Magensekretionstesten bei der chirurgischen Therapie des Uikusleidens. Langenbecks Arch. Chir., Suppl. Chir, Forum, p. 235 (1973)

25. Troid1, H., Lorenz, W., Rohde, H., Häfner, G., Ronzheimer, M. : Histamine and peptic ulcer: A prospective study on mucosal histamine concentration in duodenal ulcer patients and in control subjects suffering from various gastrointestinal diseases. Klin. Wschr. 54, 947-956(1976)

26. Willenegger, H. : Die überregionale Zusammenarbeit in der klinischen Forschung (am Beispiel der Internationalen Arbeitsgemeinschaft für Osteosynthesefragen) Chirurg 45, 494 (1974)

Professor Dr. W. Lorenz

Abteilung für experimentelle Chirurgie

und pathologische Biochemie an der

Chirurgischen Klinik der Universität

Robert-Koch-Straße 8

D-3550 Marburg a.d.Lahn

Federal Republic of Germany 